\title{
Bożena Mazurkowa, „Weksle prawdy i nieprawdy”. Studia literackie o książce oświeceniowej, Wydawnictuo Instytutu Badań Literackich PAN, Warszawa 2011, ss. 300
}

$\mathrm{R}^{\mathrm{c}}$ ecenzowana pozycja wydawnicza zawiera rozprawy poświęcone książce rozpatrywanej jako zjawisko kulturowe i ważne ogniwo społecznej komunikacji. Składa się na nią Wprowadzenie oraz pięć studiów o tekstach, które tworzą wydawniczą oprawę druków: Oświeceni literaci, wydawcy $i$ drukarze o czytelnikach, czytaniu oraz "ladajakich”, zakazanych i szacownych ksiegach, O listach dedykacyjnych Franciszka Bohomolca, O kilku okolicznościowych podarunkach książkowych z drugiej potowy XVIII wieku, Przedmowy Franciszka Bohomolca - pisarza i wydawcy oraz Pozwolenia na druk w polskiej książce oświeceniowej. Rekonesans. Dołączono do nich notę bibliograficzną (szkice, które składają się na recenzowany tom to wzbogacone wersje już publikowanych tekstów), indeks osób oraz streszczenie w języku francuskim. Tytułowa formuła książki brzmi trafnie i interesująco. Uwagę przykuwa zamieszczony w tytule cytat z tekstu Franciszka Salezego Jezierskiego pt. Niektóre wyrazy porzadkiem abecadta zebrane $i$ stosownymi do rzeczy uwagami objaśnione, do którego autorka odsyła w pierwszym szkicu („Książki to są weksle prawdy i nieprawdy, mające wypłacać wiadomości w potomności”, s. 25-26).

Poszczególne części tworzą zgrabną, przemyślaną kompozycję. Łączy je temat i optyka badawcza. Każdy tekst dotyczy innego elementu ramy wydawniczej utworów. Przedmiotem refleksji badawczej są przedmowy, aprobaty cenzorskie, przypisania i listy dedykacyjne. Wprowadzały one, dopełniały oraz zamykały dzieła w dawnych edycjach. Autorkę interesuje złożona rola wypowiedzi o charakterze metatekstowym.

We Wprowadzeniu autorka przedstawiła stan badań, omówiła przyjęte założenia metodologiczne i podała zasady transkrypcji. Okazuje się, że publikowane dotychczas prace o ramie wydawniczej, choć liczne - autorka przyznaje, że w krótkim słowie wstępnym nie sposób, nawet pobieżnie, 
omówić aktualnego stanu badań nad tymi zagadnieniami ze względu na ogromną, zróżnicowaną tematycznie i materiałowo liczbę publikacji, które im dotąd poświęcono - dalekie są od wyczerpania tego zagadnienia. Ze względu na jego obszerność, przywołuje zatem tylko najważniejsze publikacje, w całości lub w znacznej części poświęcone ramie dzieł dawnych. Wśród wymienionych znalazły się prace Renardy Ocieczek oraz innych badaczy z kręgu śląskiej polonistyki, do którego należy również autorka recenzowanej książki. Mimo istnienia interpretacyjnych wzmianek, do których odwołuje się autorka, nikt nie opracował przed nią tego zagadnienia w tak pełnym wymiarze.

Dwa pierwsze szkice (Oświeceni literaci, wydawcy i drukarze o czytelnikach, czytaniu oraz "ladajakich”, zakazanych i szacownych ksiegach i O listach dedykacyjnych Franciszka Bohomolca) poświęcone są opiniom oświeconych o książkach, czytaniu i czytelnikach oraz listom dedykacyjnym Franciszka Bohomolca. Listy te występowały w drukach oświeceniowych najliczniej. Wypowiedź o formie i funkcjach słowa drukowanego skupia wiele różnych problemów. Autorka skrupulatnie zebrała wypowiedzi na temat właściwego traktowania dzieł i autorów, poszanowania słowa drukowanego, świadomej lektury oraz problemu drukowania dla zysku. Wśród cytowanych autorów pojawiają się: Ignacy Krasicki, Stanisław Konarski, Franciszek Salezy Jezierski i publicyści „Monitora”. Mazurkowa zwróciła uwagę na pojawiającą się w ich wypowiedziach kwestię nikłego zainteresowania lekturą i nabywaniem nowych dzieł, a także niewłaściwego korzystania z książek. To ujęcie problemu staje się komplementarne wobec opracowania Teresy Kostkiewiczowej $^{21}$.

Szkic drugi pt. O listach dedykacyjnych Franciszka Bohomolca, jeden z dwóch w całości poświęconych jezuickiemu pisarzowi i znakomitemu wydawcy Franciszkowi Bohomolcowi, prezentuje prefekta stołecznej drukarni jezuickiej jako autora listów dedykacyjnych. Rozprawka jest udaną próbą ustalenia, czym edytor kierował się przy wyborze adresatów listów (pozycja adresata, emocjonalne więzy, konkretne okoliczności) i jak wy-

${ }^{21}$ T. Kostkiewiczowa, „Księgi, wiersze, dzienniki...”. O poglądach na książki i czytanie w epoce oświecenia $i$ w pismach Ignacego Krasickiego, [w:] eadem, Studia o Krasickim, Warszawa 1997, red. P. Matuszewska, B. Zakrzewski, Wrocław 1991. 
glądał stosunek wydawcy do zastanych konwencji. Przekonująco dowodzi, że Bohomolec podporządkowuje laudacyjne wizerunki nowemu wzorcowi osobowemu, postulowanemu w czasach wielkich przemian. Jezuita nie zrezygnuje przy tym całkowicie z tradycyjnych metod laudacji, choć nie przystawały one już do ówcześnie preferowanych kryteriów wartościowania człowieka. Preferuje formę pochwały pośredniej, czym daje wyraz prawdziwej sztuki komplementowania. Należy zgodzić się z autorką, że największym osiągnięciem Bohomolca jako autora listów dedykacyjnych było to, że nadał on pochlebnym opiniom charakter powszechnych, bezstronnych sądów.

Szkic trzeci pt. O kilku okolicznościowych podarunkach książkowych $z$ drugiej potowy XVIII wieku poświęcony jest książkom, które w czasach stanisławowskich z różnych okazji składano w podarunku. Do takiego prezentu darczyńcy załączali stosowny, przez siebie już napisany utwór okolicznościowy. Mazurkowa słusznie widzi w tym przejaw zmian zachodzących w ówczesnej obyczajowości i kulturze i odbicie mody na urządzanie imienin. Autorka zwróciła uwagę na emocjonalny aspekt podarunku - książka stała się materialną pamiątką uczuciowych więzi międzyludzkich. Punkt wyjścia do rozważań stanowią następujące teksty: Marcin i Joachim Bielscy, Kronika polska, Kajusz Korneliusz Tacyt, Dzieła wszystkie, t. 1, Dowód z początków prawa przyrodzonego, Jean François de La Croix, Doctionnaire portatif historique des femmes célèbres, Jacques Ballexserd, Sposób dla rodziców fizycznego wychowania dzieci, Józef Kajetan Skrzetuski, Mokotów, Modlitwy ks[iężny] I[zabeli] C[zartoryskiej], rymem związane w dzień jej imienin.

Część czwarta, poświęcona przedmowom Franciszka Bohomolca pokazuje, w jaki sposób znany komediopisarz i wydawca kreował własny wizerunek wydawcy. To mniej znane, choć równie interesujące oblicze autora Matżeństwa z kalendarza. Autorka ujawniła też strategię bohomolcowego dialogu z czytelnikiem, polegającą na skłanianiu go do refleksji nad przedstawionymi sądami i zajęcia stanowiska w konflikcie. Przekonująco dowodzi, że przedmowy zawierają jego autorską koncepcję edytorską. Kontynuacja staropolskich wzorów graniczy tu z nowatorstwem. Ze szkicu wyłania się wizerunek człowieka, który czuł się zobowiązany do przygotowania czytelnika do obcowania z tekstem dawnym. Jego polityka wydawnicza była przemyślana i świadoma, edytor dążył do wznawiania dorobku 
pisarzy staropolskich, szczególnie renesansowych, co wiązało się z programowych dla polskiego oświecenia nawiązywaniem do wybitnych dokonań rodzimego piśmiennictwa. Bohomolec jawi się jako edytor, który wyłamywał się ze zwyczajów powszechnie praktykowanych w przedmowach - rezygnował z rozbudowanej pochwały dzieła. Wyjaśniał, edukował, instruował. Przekazywał istotne i ważne informacje.

Książkę zamyka studium pt. Pozwolenia na druk w polskiej książce oświeceniowej. Rekonesans. Pisząc o aprobatach cenzorskich autorka zwróciła uwagę na fakt, jak ważnym i czytelnym sygnałem przemian instytucji cenzury w dobie oświecenia był sposób formułowania pozwoleń na druk dzieł. Przypomniała nazwiska cenzorów i przybliżyła ich sylwetki, kreśląc krąg osób, których opinie miały bezpośredni wpływ na publikację wielu dzieł. Przywołała między innymi Jana Bohomolca, brata Franciszka, cenionego autora Diabta w swojej postaci. Interesują ją szczególnie wypowiedzi wychodzące poza urzędowe, oficjalne formuły, zwykle o charakterze krytycznoliterackim. Analiza wykazała, że w czasach, gdy nie wykształciła się zinstytucjonalizowana krytyka literacka, rekomendacje cenzorskie okazywały się ważnym ogniwem pośrednictwa w procesie lektury między autorem dzieła i czytelnikami. Pochlebne wypowiedzi o dopuszczonych do druku książkach były swoistą formą reklamy. To jeden z wielu ciekawych aspektów tego zagadnienia.

Bożena Mazurkowa udowodniła, że przywołane w rozważaniach teksty pod wieloma względami godne są zainteresowania, stanowiąc atrakcyjny materiał źródłowy do badań nad książką jako podstawowym w Wieku Świateł środkiem komunikacji literackiej i przekaźnikiem idei. Należy zaznaczyć, że uwzględniła w badaniach trudno dostępne edycje osiemnastowieczne, ponownie wprowadzając je w orbitę dyskursu literaturoznawczego. Książka stanowi ważną pozycję wydawniczą o potencjalnie szerokim kręgu odbiorców. Przybliża miejsce i rolę książki w życiu osiemnastowiecznego społeczeństwa.

Danuta Kowalewska (Toruń) 